Fernando Rodrigues Peixoto Quaresma ${ }^{1}$

Airton Tetelbom Stein ${ }^{2}$

\title{
Attributes of primary health care provided to children/adolescents with and without disabilities
}

\author{
Atributos da atenção primária prestada \\ às crianças/adolescentes com e sem deficiência
}

${ }^{1}$ Programa de PósGraduação em Promoção da Saúde, Universidade Luterana do Brasil (Ulbra). Av. Teotônio Segurado, Centro. 77000-000 Palmas TO Brasil.

quaresma@ceulp.edu.br

${ }^{2}$ Departamento de Medicina Preventiva, Fundação

Universidade Federal de

Ciências da Saúde de Porto

Alegre.

\begin{abstract}
This study sought to compare the attributes of the Primary Health Care (PHC) provided by caregivers of the Family Health Strategy (FHS) to children and adolescents with and without physical disabilities in Palmas (State of Tocantins, Brazil). This is a cross-sectional, descriptive study with a quantitative approach. For data collection, the PCA Tool-Brazil (child version) was applied to caregivers of children and adolescents residing and registered in family health teams. The attributes of primary care were evaluated through scores measured according to the criteria of the instrument. The results indicated that three attributes had scores above the cutoff point for the physically disabled population and two attributes for the population without disabilities. Overall, the data showed no significant differences between children with and without disabilities from the standpoint of caregivers. The general score also showed a below satisfactory score in both groups. The evaluation of the attributes of the PHC was characterized as low-quality care to children and adolescents, be they physically challenged or not, which highlights the fact that the biggest challenges lie in ensuring health care to children and adolescents.
\end{abstract}

Key words Primary health care, Evaluation of services, Physically disabled person
Resumo Este estudo objetivou comparar os atributos da Atenção Primária à Saúde (APS) prestada pelas equipes da Estratégia Saúde da Família (ESF) às crianças e adolescentes com e sem deficiência física em Palmas (TO). Trata-se de um estudo transversal, descritivo de abordagem quantitativa. Para coleta de dados utilizou-se o instrumento PCATool-Brasil (versão criança), aplicado aos cuidadores das crianças e adolescentes residentes e cadastradas em equipes de saúde da família. Os atributos da atenção primária foram avaliados através dos escores aferidos de acordo com critérios do instrumento. Os resultados registraram que três atributos apresentaram escores acima do ponto de corte para a população deficiente e dois para a população sem deficiência. Em geral os dados não apresentam diferenças significativas entre crianças com e sem deficiência segundo a visão dos cuidadores. O escore geral também mostrou valor abaixo do satisfatório nos dois grupos. A avaliação dos atributos da APS caracterizou-se como um atendimento de baixa qualidade à população infanto-juvenil, independente de ter ou não deficiência física, ressaltando que os desafios maiores são a garantia da atenção à saúde para crianças e adolescentes.

Palavras-chave Atenção primária à saúde, Avaliação dos serviços, Pessoa com deficiência fisica 


\section{Introduction}

The population of children and adolescents physically challenged represents groups exposed to greater vulnerabilities caused by a context of social inequality, resulting from the historical process of exclusion ${ }^{1}$. Discrimination based on disability is shown by a number of barriers that limit access to various services, especially health, including physical barriers, means of transportation ${ }^{2}$, inadequate preventive care, dissatisfaction with care ${ }^{3}$, professional inadequacy ${ }^{4}$, miscommunications and failures of the health care financial systems $\mathrm{s}^{1,3,5}$.

Global discussion concerning health needs of populations, including vulnerable groups (impaired people), has been marked by the development of several healthcare models, such as the premises of PHS that were presented more than 30 years ago at the International Conference on Primary health care in Alma Ata - 1978. The PHS principles aimed at a conceptual alignment to place the PHS as a fundamental device of complex gears of integrated health care networks ${ }^{6}$. The search for convergent actions to implement PHS principles has become the main strategy for the organization of public health services?

Since 1980, Brazil has refocused the national health model, historically marked by highly complex and costly actions and services, to a health care network based on the principles and recommendations of Alma Ata ${ }^{8}$. The strengthening of primary care was obtained through major changes in the organization, financing and provision of services, which were marked by decentralized actions for health promotion and expansion of health care based on the model of Family Health Strategy (FHS - a program of the Brazilian federal government), chosen as the backbone of the Primary Health Care policy (PHS) ${ }^{8,9}$.

Studies show that health care systems based on the principles of PHS, structured in accordance with its ordering attributes, are more effective, most satisfactory for the population, with lower costs and greater equity, even in a context of great social inequity ${ }^{10,11}$.

An important instrument to assess the structure and process at PHS was developed ${ }^{11}$. The Primary Care Assessment Tool (PCATool) has already been validated in Brazil and it allows to measure the presence and extension of essential and derivate attributes of PHS for health care services. It can be applied to professionals in health care or users and it is directed to health actions to adults and children (in distinct version), reflecting the experience of different groups in health care ${ }^{12,13}$.
For Starfield ${ }^{11}$, PHS has four essential attributes: first contact, continuity or longitudinality, comprehensiveness and coordination and two derivate attributes: family and community guidance.

The first contact implies access and use of services for each new problem or for a routine follow-up of health. Longitudinality shows continual health care, as well as the use of services overtime by the users. Integrality consists of services offered by caregivers to meet the most common needs of the population. It also establishes the responsibility for other points of health care and adequate recognition of problems that cause diseases. Moreover, integrality offers preventive and care services and warranty of several service types. Coordination refers to the professional/ service of PHS as a regulator for the access to health services at other levels of the health system, such as diagnostic services and specialized references. Family guidance shows whether the health care considers the family as a subject of attention. Community guidance presupposes the recognition of Family needs in terms of physical, economic, social and cultural contexts where the community is inserted ${ }^{11}$.

Thus, it becomes important to identify and measure PHS attributes, once the level of orientation of a service for PHS contributes to implement effective and equalitarian public policies mainly to the children and adolescents, who face even more evident inequalities when these subgroups are composed of physically challenged people ${ }^{14,15}$.

This study aimed to compare the quality of the Primary Health Service (PHS) offered to children/adolescents with or without disabilities in the municipality of Palmas, state of capital of Tocantins, Brazil, based on the evaluation of caregivers.

\section{Method}

We conducted a cross-sectional and descriptive study, using a quantitative approach, in the municipality of Palmas. Palmas has an estimated population of 228,332 and it is the capital city of Tocantins State. The municipality has 39 service units of PHC distributed in strategic locations to ensure access of the population. Thirty-seven teams are from the Family Health Strategy (FHS), two from FHS-rural and two are characterized as polyclinics. All units have operate for more than three years. 
The target population comprises caregivers of children/adolescents between 12-18 years of age, properly matriculated in the public school system, residing and registered in the regions served by the caregivers of PHS in the municipality of Palmas, Tocantins State. We considered losses people that refused to participate in the study and those who were not located after three attempts for an interview at the known address or because of incorrect address.

After applying these criteria, we carried out the stages to achieve the proposed objectives. Stage I (Figure 1) corresponded to the selection and contact with schools. The sample was defined based on the 73 schools that comprise the public school system of the municipality. We selected 49 schools (67\%) with students within the age range of the study.

The sample size calculation was performed assuming prevalence of physical disability of $2.88 \%{ }^{16}$, acceptable error $1.5 \%$, confidence level $95 \%$ and design effect 2, with the total sample estimated at 651 individuals. A method of cluster sampling, where each school formed a cluster, was used ${ }^{16}$. The selection of students was established proportionally to each school in the sample calculation. For that purpose, attendance

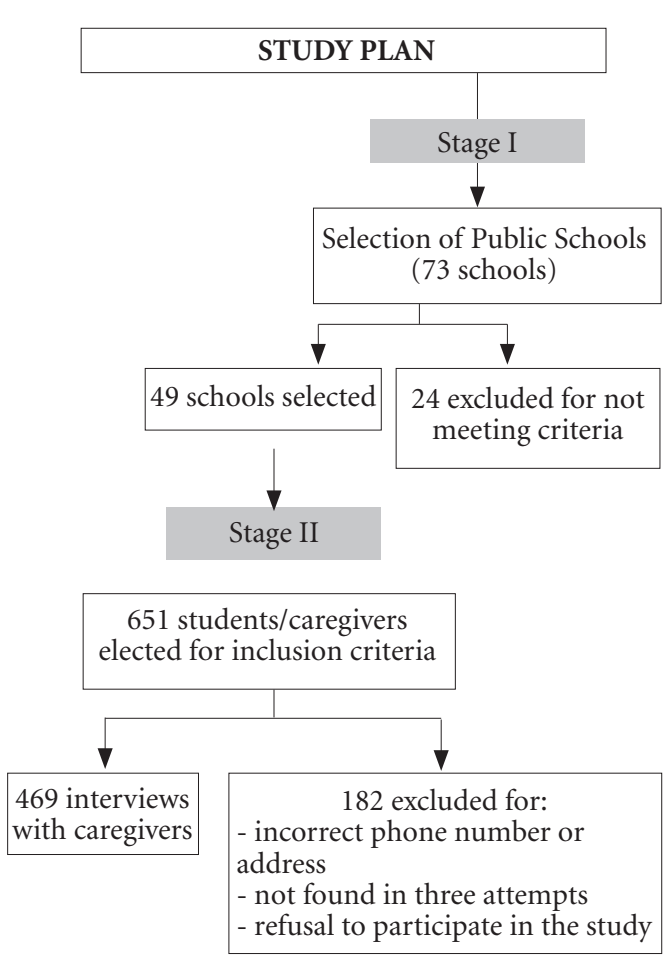

Figure 1. Study plan for sample collection. card were arranged in ascending order from 7th grade of elementary school to 3rd year of high school where all the attendance cards were part of a single list. We selected the first student of the attendance card, using a leap of 24 students for the next, according to the selection method. A database was built with information about the stakeholders (name, address and telephone number) to schedule the interviews.

In Stage II (Figure 1), data were collected in two phases: - in the first one, a telephone contact was made to present the purpose of the study and schedule the interview; - in the second one, we collected information at their residence or work, or in some cases at the school of the child/adolescent.

This research used the definition "disabled person" to individuals with absence or impairment of a body part and/or having difficulty or inability to walk, move or handle objects ${ }^{17}$. To facilitate the identification, a folder with figures of the main characteristics or manifestations of physical disabilities was created.

Inclusion criteria involved the connection of children/adolescents with the use of Family Health Strategy. Exclusion criteria: children with canceled registration that evaded school or was transferred to other schools during the study period. Those who refused to participate in the study, or who were not located after three attempts of the interviewer at the address or because of incorrect address were considered losses.

Data collection was performed using the instrument PCATool - Primary Care Assessment Tool - Brazil Child Version (PCATool-VC), validated in Portuguese ${ }^{12}$, which measures the extent of the essential and derivate attributes of the PHS in child health care services based on family/ caregiver. Fifty-five items divided into 10 components compose the extent of attributes measured classified as essential (first contact, coordination, longitudinality, comprehensiveness and coordination of care) and derivatives (community and family guidance and cultural competence), investigating the "Affiliation Degree" to the regular source of care. The instrument includes Likert Scale responses with interval from 1 to 4 for each attribute evaluated $(4=$ definitely yes, $3=$ probably yes, 2 = probably no, $1=$ definitely not, and 9 $=$ do not know $/$ cannot remember $)^{12}$.

Data on demographic and socioeconomic characteristics of the caregiver (age, gender, social class, income, marital status, employment status, receipt of government benefits) and children/adolescents (age and disability) were obtained. 
The statistical analysis was performed using the statistical package SPSS (Statistical Package for Social Sciences) version 18.0 for Windows to assess the distribution of social, economic and demographic categorical variables between groups of students with and without physical disabilities. We used bivariate statistics (chi-square).

To check the quality of care in PHC, scores of each attribute were calculated, obtained from the means of the composing items. All scores of each attribute was transformed into a continuous range between 0-10 using the formula: Adjusted score $=[($ score obtained -1$) /(4-1)] \times 10$ to allow the calculation of "Essential score" and "Overall Score" of PHS ${ }^{12}$.

The "Essential score" was measured by adding the mean scores of components belonging to the "Essential Attributes" to the value assigned to "Degree of Affiliation" and divided by the number of components. The calculation of the "Main Score", in turn, followed the same principle, having increased, however, the mean scores of the three attributes derived from PHS. The cut point for scores $\geq 6.6$ indicates adequate presence and satisfactory values of the attributes of $\mathrm{PHS}^{12,13}$.

The study was submitted to the Ethics Committe in Research of the Lutheran University Center of Palmas - CEULP/ULBRA, and was approved. It was also approved by the State and Municipal Departments of Education. Ethical principles were respected at all stages of research in compliance with CNS Resolution No. 466/12 ${ }^{18}$ that regulates research involving human subjects.

\section{Results}

Among the 656 eligible according to the inclusion criterion, 469 participants were interviewed. Fifty-two people (7\%) were not found and were considered a loss because of telephone registration problems, or they were not found at home after three attempts of the interviewer at the address, or due to incorrect address.

Table 1 shows the main socio-demographic characteristics of the families/caregivers of the children/adolescents with physical disabilities.

The average age was $14.9(\mathrm{SD} \pm 1.9)$ without disabilities, with disabilities $13.2(\mathrm{SD} \pm 1.3)$.

Among the demographic characteristics, women were identified as the main caregivers of children/adolescents accounting for 404 (87\%) in the group without disabilities and four $(80 \%)$ in the physically-challenged group. Of these, the majority of caregivers $(335-71 \%)$ were stu- dents' mothers. Regarding the age, stratification per group showed a greater prevalence between 31 and 60 years old $(406-88.1 \%)$ in the group without disabilities and five (100\%) in the group with disabilities.

The average per capita income was $\mathrm{R} \$$ 2,101.13 (SD $\pm 1,743.8$ ) for nondisabled and $\mathrm{R} \$$ 996.00 (SD \pm 319.5 ) of the disabled population, prevailing in Class $\mathrm{C}$ to $\mathrm{E}$ for both with 367 (SD \pm $79.1 \%)$ without disabilities and five (100\%) with disabilities. The employment scenario shows that 293 (63.4\%) without disabilities are currently employed and two (40\%) with disabilities are unemployed.

In terms of benefits granted by the government, $114(24.6 \%)$ in the group without disabilities receive some benefit and no member of the group with disabilities reported receiving.

The average age of children/adolescents was $14.9(\mathrm{SD} \pm 1.9)$ in the group of non-disabled and $13.2(\mathrm{SD} \pm 1.3)$ in the group with disabilities. Regarding the PHS link with family/caregivers, in the group without disabilities, 260 (56\%) took the children/adolescents to FHS, while in the group with disabilities only one family (20\%) reported taking the children to FHS.

The mean scores of attributes of FHS in PHS regarding caregivers of children/adolescents are shown in Table 2.

The "Affiliation" component had mean scores above the cutoff point for both groups, 9.4 for the group without disabilities and 9.3 for the group with disabilities. The mean score of the "Use" component to people without disabilities showed greater value $[7.2(\mathrm{SD} \pm 2.2)]$ than that of the disabled group [5.5 $(\mathrm{SD} \pm 2.8)]$.

The "Coordination" component had mean scores for the 'System Information' attribute of $6.9(\mathrm{SD} \pm 2.0)$ for the non-disabled and 6.6 (SD \pm 1.5 ) for the disabled.

The 'Use' attribute of the component "Access First Contact" had scores above the cutoff for the non-disabled [7.2 ( $\mathrm{SD} \pm 2.2)]$ and below the cutoff point $[5.5(\mathrm{SD} \pm 2.8)]$ for the disabled.

The average "Essential Scores" was without disabilities $5.6(\mathrm{SD} \pm 0.7)$ and with disability 5.3 $(\mathrm{SD} \pm 0.4)$. Moreover, the average of "General Scores" was 5.1 without disabilities $(S D \pm 0.7)$ and $4.7(\mathrm{SD} \pm 0.3)$ with disabilities.

\section{Discussion}

Comparing the main demographic socioeconomic characteristics of populations with and 
Table 1. Comparison of demographic socioeconomic characteristics, social support, children/adolescent age, PHS score of attributes and ESF use of students with and without physical disabilities, Palmas/TO, 2013.

\begin{tabular}{|c|c|c|}
\hline Variables & $\begin{array}{l}\text { Without Disabilities } \\
\text { [median(dp)/\%] } \\
n=464\end{array}$ & $\begin{array}{c}\text { With Disabilities } \\
\text { [median }(\mathbf{d p}) / \%] \\
\mathbf{n}=\mathbf{5}\end{array}$ \\
\hline \multicolumn{3}{|l|}{ Gender } \\
\hline Male & $60(13 \%)$ & $1(20 \%)$ \\
\hline Female & $404(87 \%)$ & $4(80 \%)$ \\
\hline \multicolumn{3}{|l|}{ Age } \\
\hline From 18 to 30 years old & $32(7 \%)$ & - \\
\hline From 18 to 60 years old & $406(88 \%)$ & $5(100 \%)$ \\
\hline more than 60 years old & $26(5 \%)$ & - \\
\hline \multicolumn{3}{|l|}{ Economic class (ABEPa) } \\
\hline $\mathrm{A} 1 \mathrm{~A} 2-\mathrm{B} 1 \mathrm{~B} 2$ & $97(21 \%)$ & - \\
\hline $\mathrm{C} 1 \mathrm{C} 2-\mathrm{DE}$ & $367(79 \%)$ & $5(100 \%)$ \\
\hline Per Capita Income & $2,101.13(1,743.8)$ & $996.00(319.5)$ \\
\hline \multicolumn{3}{|l|}{ Marital status } \\
\hline Without partner & $114(25 \%)$ & - \\
\hline With partner & $350(75 \%)$ & $5(100 \%)$ \\
\hline \multicolumn{3}{|l|}{ Occupational status } \\
\hline Working & $294(64 \%)$ & $2(40 \%)$ \\
\hline Not working & $170(36 \%)$ & $3(60 \%)$ \\
\hline \multicolumn{3}{|l|}{ Receiving Benefit ${ }^{\mathrm{b}}$} \\
\hline Yes & $114(25 \%)$ & - \\
\hline No & $350(75 \%)$ & $5(100 \%)$ \\
\hline Children/adolescents age (years) & $14.9(1.9)$ & $13.2(1.3)$ \\
\hline Essential score of PHS & $5.6(0.7)$ & $5.3(0.4)$ \\
\hline General score of PHS & $5.1(0.7)$ & $4.7(0.3)$ \\
\hline \multicolumn{3}{|l|}{ Link with ESF } \\
\hline Never used PHS & - & - \\
\hline$>1$ year & $204(44 \%)$ & $4(80 \%)$ \\
\hline$\leq 1$ year & $260(56 \%)$ & $1(20 \%)$ \\
\hline
\end{tabular}

"ABEP: Brazilian Association of Research Companies. ${ }^{b}$ Benefit: (Municipal, State or Federal Government).

without disabilities, we observe that disabled people have lower income, do not have employment, and receive benefits from the government, that is, they are poorer and have less purchasing power, greatly affecting the children.

Similar studies show inequalities and socioeconomic disparities ${ }^{19-21}$, which are aggravated when the subjects belong to groups with historical profile of exclusion and discrimination such as the disabled ${ }^{22}$, indigenous people ${ }^{23}$, quilombo$\operatorname{las}^{24}$, making the inequities in PHC more acute and hampering their right to health, guaranteed by the Convention on Children's Rights and, in Brazil, in the Children Statute ${ }^{25}$.

Children with disabilities require dependence and in our study, the mother was identified as the main caregiver, similar to other studies ${ }^{21,26}$ that indicate women as a predisposing factor for caregiving, since women tend to show greater willingness to use health care than men do.
Table 2. The mean score of attributes of FHS in PHC according to family/guardian of children/adolescents with and without physical disabilities in relation to health services, Palmas/TO, 2013.

\begin{tabular}{|c|c|c|}
\hline Variables & $\begin{array}{l}\text { Without Disabilities } \\
\text { mean }(\mathrm{SD} \pm) \\
\mathrm{n}=464\end{array}$ & $\begin{array}{c}\text { With Disabilities } \\
\text { mean }(\mathrm{SD} \pm) \\
\mathbf{n}=5\end{array}$ \\
\hline Degree of affiliation & $9.4(1.4)$ & $9.3(1.4)$ \\
\hline Use & $7.2(2.2)$ & $5.5(2.8)$ \\
\hline accessibility & $3.6(1.7)$ & $4.3(2.5)$ \\
\hline longitudinality & $3.7(0.9)$ & $3.5(0.3)$ \\
\hline Care Integration & $6.1(2.4)$ & $8.0\left(^{*}\right)$ \\
\hline Information System & $6.9(2.0)$ & $6.6(1.5)$ \\
\hline Available services & $4.3(1.2)$ & $3.4(1.3)$ \\
\hline Rendered Services & $3.8(2.1)$ & $4.0(1.7)$ \\
\hline Family guidance & $2.3(2.1)$ & $2.2(0.7)$ \\
\hline Community guidance & $4.4(1.7)$ & $3.0(0.7)$ \\
\hline Essential score of PHS & $5.6(0.7)$ & $5.3(0.4)$ \\
\hline General score & $5.1(0.7)$ & $4.7(0.3)$ \\
\hline
\end{tabular}

*only one individual in this evaluation. 
The main determinants for the use health care in PHC depend ${ }^{27}$ on various interrelated factors such as: (a) need for care - morbidity, seriousness and urgency of treatments; (b) users - demographic characteristics (age, gender), geographic (physical barriers), socioeconomic characteristics (income, education, expenses, occupation), cultural (religion), psychological and physical (disabilities); (c) caregivers - demographic characteristics (age, gender), graduation, professional expectation, professional experience, type of practice, salary; (d) the organization - available resources, structure (availability of doctors, hospitals, clinics), social and geographical access; (e) policies - the type of health care, financing, health insurance, amount, distribution of resources, laws and professional regulations of the system.

Studies show stagnation of caregivers to include the community into health care actions and a certain inertia at not including actions into services $^{28,29}$. These studies indicate that the process of social participation must be continuously improved.

The results obtained in the study using PCATool regarding the evaluation of health care show that, using a score $\geq 6.6$ as a parameter to indicate the presence and extent of PHC attributes, students are not present in the caregiving process for most attributes.

The scores observed for affiliation degree of students show that the family/guardians identify the FHS as a reference service for their child (children)/ adolescent (s), but the same was not observed in the access attribute of first contact.

The findings of Leão et al. ${ }^{20}$ indicate that the use of the health care can be justified by particularities in the health at this stage of life characterized by greater number of acute cases. The use of FHS by children is associated with improvements in some health indicators, such as reducing the number of deaths from diarrheal disease and respiratory tract infection in the post-neonatal period $^{30}$.

Marques et al. ${ }^{24}$ studied the characteristics of 76 families of the quilombola community in Minas Gerais and observed that the recognition of the FHS as well as its use can be justified for being the only access available to the community, far from other public health care.

The low scores found in subsection accessibility to students with physical disabilities take bigger because it portrays the perverse inequity that children / adolescents are subject to ${ }^{31}$, indicating that this attribute is a point on PHC problem.
The lack of observed longitudinality shows weak continuity of health care for schoolchildren. The ways of hiring the FHT professionals in Brazil, in general, leads to discontinuity in the composition of teams, a fact that reflects on the care provided or the weak bonding between students and family/guardians with professionals or caregivers over time ${ }^{32,33}$. Besides, there are difficulties to attract qualified professionals to work in remote areas of the country, hindering health care to those in great need (Inverse Care Law) ${ }^{33}$.

The analysis of the completeness attribute registered an unsatisfactory score, which denotes paucity of practical teamwork, reproduction or maintenance of centered model in medical care as well as the fragility to promote health and prevent specific diseases to children.

Comprehensiveness and coordination of care, according to Victora et al. ${ }^{31}$, unfold in "services rendered" and "available services". In practice, their implementation is the responsibility of the professionals engaged in the purpose of FHS and in the process of construction and improvement of SUS (public health care in Brazil). In the health sector, these attributes bring co-responsibility, and the government has a central role as well as other stakeholders with relevant roles: caregivers; private sector; universities, training institutions, health councils and researchers; and civil society.

The attribute coordination comprises two sub-items, 'care integration', which recorded scores below expectations, and 'information system' with satisfactory scores, results observed in similar studies ${ }^{20,24}$.

'Care integration' shows that ensuring continuity of care to health services at other levels of the system is inadequate, while 'information system' indicates that professionals and users have access to attendance records.

According to Almeida et al. ${ }^{34}$ PHC users claim that referrals to other levels of health care are most effective when carried out by professionals of FHS and the waiting time is shorter than when referrals are made by other sources.

The positive results found in the attribute 'information system' had specific characteristics that supported the score within expected values , but it is not necessarily a good evaluation of the attribute. Of the three items evaluated in this attribute, one depends solely on the family/guardian (submission of records of the children/adolescents and child health card, vaccination card), which obtained high scores. The other two items referring to the availability of the documents of- 
fered by children health care to family/guardian, the score was insufficient.

For derived attributes, evaluated scores were not satisfactory. Thus, family guidance and community guidance are not recognized by family/ caregiver indicating that the model for the protection of children's health is not oriented towards the primary care guidelines. FHS, as a priority for the organization and expansion of health care, must have solid bases to promote health and quality of life to individuals, families, and communities.

When comparing the PHC attributes of between students with and without physical disabilities, this study shows small differences, emphasizing that the biggest challenges lie in ensuring basic health care to children, characterized by fragmented and disjointed care with other levels of care network to children.

Among the limitations observed in this study are: a) difficulty in obtaining the cluster sample of the resulting sample calculation that, according to the selection strategy, sometimes resulted in school transfer; b) telephone contacts, incorrect or nonexistent home addresses; c) high number of refusals; difficulty to compare with similar studies due to the lack of studies reported in the literature; e) limited comparison between groups, because there was a smaller number of physically challenged children compared to non-challenged children, which hindered the significance of statistical analyses.

Finally, study draws attention to the challenges to be undertaken by PHC professionals and managers to strengthen health care to children with or without disabilities, such as ensuring that policies aimed at these groups take effect promoting improvements of health care, better qualification of caregivers to overcome barriers related to human resources and existing gaps already reported in other studies.

\section{Collaborations}

FRP Quaresma and AT Stein participated equally in all stages of the elaboration of this article.

\section{References}

1. Jones LBS, Bellis MA, Wood S, Hughes K, McCoy E, Eckley L, Bates G, Mikton C, Shakespeare T, Officer A. Prevalence and risk of violence against children with disabilities: a systematic review and meta-analysis of observational studies. Lancet 2012; 380(3):899-907.

2. Interdonato GC, Greguol M. Qualidade de vida e prática habitual de atividade física em adolescentes com deficiência. Rev. bras. crescimento desenvolv. hum. 2011; 21(2):282-295.

3. Morrison EH, George V, Mosqueda L. Primary care for adults with physical disabilities: perceptions from consumer and provider focus groups. Fam Med 2008; 40(9):645-651.

4. Evans SA, Airey MC, Chell SM, Connelly JB, Rigby AS, Tennant A. Disability in young adults following major trauma: 5 year follow up of survivors. BMC Public Health 2003; 3:8.

5. Gotler RS. The Science. Art, and Policy of Primary Care. Ann fam med 2009; 7(3):194-195.

6. Miller WL, Crabtree BF, Nutting PA, Stange KC, Jaén CR. Primary Care Practice Development: A Relationship-Centered Approach. Ann fam med 2010; 8(Supl. 13):S68-S79.

7. Almeida C. Eqüidade e reforma setorial na América Latina: um debate necessário. Cad Saude Publica 2002; 18(Supl.):23-36.

8. Harris M, Haines A. Brasil's Family Health Programme. BMJ 2010; 341:c6542. 
9. Brasil. Ministério da Saúde. Departamento de Atenção Básica. Programa Saúde da Família. Rev Saude Publica 2000; 34(3):316-319.

10. Van Stralen CJ, Belisário AS, Van Stralen TBS, Lima, AMD, Massote AW, Oliveira CL. Percepção dos usuários e profissionais de saúde sobre atenção básica: comparação entre unidades com e sem saúde da família na Região Centro-Oeste do Brasil. Cad Saude Publica 2008; 24(Supl. 1):148-158.

11. Starfield B. Atenção Primária: equilíbrio entre necessidades de saúde, serviços e tecnologia. Brasília: UNESCO, Ministério da Saúde; 2002.

12. Brasil. Ministério da Saúde (MS). Secretaria de Atenção em Saúde. Departamento de Atenção Básica. Manual do instrumento de avaliação da atenção primária à saúde: primary care assessment tool - PCAtool. Brasília: MS; 2010.

13. Harzheim E, Starfield B, Rajmil L, Álvarez-Dardet C, Stein A. Internal consistency and reliability of Primary Care Assessment Tool (PCATool-Brasil) for child health services. Cad Saude Publica 2006; 22(8):1649-59.

14. Starfield B. The hidden inequity in health care. I J Equity Health 2011; 10:15.

15. Fundo das Nações Unidas para Infância (Unicef). [homepage na internet]. Mainstreaming disability in the development agenda. [acessado 2011 set 1]. Disponível em: http://www.un.org/disabilities/documents /reports/e-cn5-2008-6.doc

16. Barros FC, Victoria CG. Epidemiologia da saúde infantil: um manual para diagnósticos comunitários. São Paulo: Hucitec, Unicef; 1991.

17. World Health Organization (WHO). 2001. [homepage na internet]. International Classification of functioning, disability, and health. [acessado 2011 out 1]. Disponível em: http://www.who.int/classifications/icf

18. Brasil. Ministério da Saúde (MS). Conselho Nacional de Saúde. Resolução no 466, de 12 de dezembro de 2012. Diário Oficial da União 2013;

19. Pimentel J. Determinantes Sociais da Saúde em debate em evento internacional na Fiocruz [homepage na internet]. Rio de Janeiro: Portal DSS Brasil. [acessado 2013 nov 1]. Disponível em: http://dssbr.org/ site/2013/10/determinantes-sociais-da-saude-emdebate-em-evento-internacional-na-fiocruz/

20. Leão CDA, Caldeira AP, Oliveira MMC. Atributos da atenção primária na assistência à saúde da criança: avaliação dos cuidadores. Rev Bras Saude Mater Infant 2011; 11(3):323-334.

21. Sung NJ, Suh SY, Lee DW, Yupahn H, Choi YJ, Lee JH. Patient's assessment of primary care of medical institutions in South Korea by structural type. Int J Qual Health Care 2010; 22(6):493-499.

22. Reem M, Ghandour PH, Holly AG, Ashley MA, Schempf H, Bonnie BS, Kogan MD, Jones JR, Nichols D. Healthy people 2010 leading health indicators: how children with special health care needs fared. Am J Public Health 2013; 103(6):1257-1263.

23. Coimbra Júnior CEA, Santos RV, Welch JR, Cardoso AM, de Souza MC, Garnelo L, Rassi E, Follér ML, Horta BL. The first national survey of indigenous people's health and nutrition in Brazil: rationale, methodology, and overview of results. BMC Public Health 2013; 13:52.
24. Marques AS, Freitas DA, Leão CDA, Oliveira SKM, Pereira, MM. atenção primária e saúde materno-infantil: a percepção de cuidadores em uma comunidade rural quilombola. Cien Saude Colet 2013; 16(7):229-238.

25. Brasil. Lei 8.069 , de 13 de julho de 1990. Dispõe sobre o Estatuto da Criança e do Adolescente e dá outras providências. Diário Oficial da União 1990; 16 jul.

26. Schraiber LB, Figueiredo WS, Gomes R, Couto MT, Pinheiro TF, Machin R, Silva GSN, Valença O. Necessidades de saúde e masculinidades: atenção primária no cuidado aos homens. Cad Saude Publica 2010; 26(5):961-970.

27. Macinko J, Souza M, Guanais F, Simões C. Going to scale with community based primary care an analysis of the family health program and infant mortality in brazil, 1999-2004. Soc Sci Med 2007; 65 (10):2070-2080.

28. Leonardo BR, Rachel SBCC, Sampaio KJAJ. Participação popular e o controle social como diretriz do SUS: uma revisão narrativa. Saúde em Debate 2013; 37(96):139-147.

29. Malhotra NK. Pesquisa de Marketing: Uma orientação aplicada. 6a ed. Rio de Janeiro: Bookman; 2010.

30. Aquino R, Oliveira NF, Barreto ML. Impact of the Family Health Program on infant mortality in Brazilian municipalities. Am J Public Health 2009; 99(1):87-93.

31. Victora CG, Barreto ML, Leal MC, Monteiro CA, Schmidt MI, Paim J, Almeida CM, Bahia L, Travassos CMR, Reichenheim M, Barros FC. Saúde no Brasil: Condições de saúde e inovações nas políticas de saúde no Brasil: o caminho a percorrer. Lancet 2011;377(9782):90-102.

32. Medeiros CR, Junqueira AG, Schwingel G, Carreno I, Jungles LA, Saldanha OM. Nurses and doctors turnover: an impasse in the implementation of the Family Health Strategy. Cien Saude Colet 2010; 15(Supl. 1):1521-1531.

33. Gray AM. Inequalities in health. The Black Report: a summary and comment. Int J Health Serv 2012; (12):349-380.

34. Almeida PF, Giovanella L, Mendonça MH, Escorel S. Desafios à coordenação dos cuidados em saúde: estratégias de integração entre níveis assistenciais em grandes centros urbanos. Cad Saude Publica 2010; 26(2):286-298.

Artigo apresentado em 17/06/2014

Aprovado em 18/03/2015

Versão final apresentada em 20/03/2015 